\title{
Carica papaya Linn. fruit extract inhibited the activities of aldose reductase and sorbitol dehydrogenase: possible mechanism for amelioration of diabetic complications
}

\author{
Mutiu Idowu Kazeem ${ }^{1 *}$ (D), Ayotomiwa Adeyinka Adeyemi ${ }^{1}$, Abiola Fatimah Adenowo ${ }^{2}$ and \\ Mushafau Adewale Akinsanya ${ }^{2}$
}

\begin{abstract}
Background: Diabetes mellitus is a metabolic disorder which is associated with debilitating complications including eye disease, kidney disorder, and diabetic foot disease. One of the mechanisms implicated in the pathogenesis of diabetic complications is the polyol pathway. This study evaluated the inhibitory effect of aqueous extract of four tropical fruits, namely apple (Malus domestica Borkh.), banana (Musa paradisiaca Linn.), pawpaw (Carica papaya Linn.), and watermelon (Citrullus lanatus (Thunb.) Matsum \& Nakai), on the activities of polyol pathway enzymes (aldose reductase and sorbitol dehydrogenase).

Results: All the fruits, with the exception of banana, displayed stronger inhibition of sorbitol dehydrogenase than aldose reductase which culminated in low $I_{50}$ for the inhibition of sorbitol dehydrogenase. Of the fruit extracts tested, pawpaw inhibited both aldose reductase and sorbitol dehydrogenase most effectively with $\mathrm{IC}_{50}$ of $150.78 \mu \mathrm{g} / \mathrm{mL}$ and $46.30 \mu \mathrm{g} / \mathrm{mL}$, respectively. Lineweaver-Burk plot also revealed that the pawpaw extract inhibited aldose reductase competitively while sorbitol dehydrogenase was inhibited in a mixed non-competitive manner.

Conclusion: Aqueous extract of pawpaw fruit effectively inhibited polyol pathway enzymes, and this may be attributed to rich nutritional and phytochemical composition of the fruit. Consequently, the consumption of pawpaw fruit may contribute to the amelioration of diabetic complications.
\end{abstract}

Keywords: Diabetes mellitus, Carica papaya, Diabetic complications, Aldose reductase, Sorbitol dehydrogenase

\section{Background}

Polyol pathway is an alternative pathway for the metabolism of glucose, in which glucose is converted to sorbitol and fructose, with the aid of aldose reductase and sorbitol dehydrogenase, respectively [1]. This pathway is activated in many cells when intracellular glucose concentrations are

\footnotetext{
* Correspondence: mikazeem@gmail.com; idowu.kazeem@lasu.edu.ng 'Department of Biochemistry, Faculty of Science, Lagos State University, Ojo, Lagos, Nigeria

Full list of author information is available at the end of the article
}

high and caused accumulation of sorbitol and fructose [1], which elicit myriad of pathological processes including oxidative stress and formation of advanced glycation end products. Oxidative stress and formation of advanced glycation end products (AGEs) is implicated in many diabetic complications such as retinopathy, neuropathy, and nephropathy $[2,3]$. These complications are associated with reduced productivity and life span of the patients and caused huge cost to the individual and government.

\section{Springer Open}

(๑) The Author(s). 2020 Open Access This article is licensed under a Creative Commons Attribution 4.0 International License, which permits use, sharing, adaptation, distribution and reproduction in any medium or format, as long as you give appropriate credit to the original author(s) and the source, provide a link to the Creative Commons licence, and indicate if changes were made. The images or other third party material in this article are included in the article's Creative Commons licence, unless indicated otherwise in a credit line to the material. If material is not included in the article's Creative Commons licence and your intended use is not permitted by statutory regulation or exceeds the permitted use, you will need to obtain permission directly from the copyright holder. To view a copy of this licence, visit http://creativecommons.org/licenses/by/4.0/. 
In order to manage diabetes and its complications, the ultimate goal is glycemic control [4], and this can be achieved via strict dietary regimen, engagement in physical activity, and use of oral hypoglycemic agents/insulin. Consumption of diets rich in fruits has been attributed to reduced risk of diabetes and effective management of diabetes-induced hyperglycemia as well as secondary complications $[5,6]$. Fruits are important component of diet which contains several nutrients (e.g., minerals and vitamins) and phytochemicals (e.g., polyphenols) that contributes to their pharmacological effects in both healthy and diseased states [7]. They come in various colors and taste which may be a function of the nature of the phytochemicals present in them.

Due to the high clinical and economic burden placed on diabetic individuals by debilitating complications, there is the need to consciously include fruits in the management of diabetes mellitus. Though some studies have examined the beneficial effect of consumption of fruits in diabetes and its complications $[8,9]$, there is dearth of information on the potential mechanisms by which these effects are elicited. Consequently, this study is aimed at evaluating the inhibitory effect of some fruits on polyol pathway enzymes (aldose reductase and sorbitol dehydrogenase) and their kinetics of inhibition. This will determine the potency of the selected fruits in managing diabetes and its complications.

\section{Methods}

\section{Chemicals}

Human recombinant aldose reductase, DL-glyceraldehyde, glucose, lithium sulfate, 2-mercaptoethanol, NADPH, quercetin, dimethylsulfoxide, sorbitol, sorbitol dehydrogenase, and $\mathrm{NAD}^{+}$were obtained from Sigma-Aldrich (St. Louis, MO). All other chemicals and solvents were of analytical grade and were obtained from local companies.

\section{Sample collection and preparation}

Fresh samples of selected fruits, apple (Malus domestica Borkh.), banana (Musa paradisiaca Linn.), pawpaw (Carica papaya Linn.), and watermelon (Citrullus lanatus (Thunb.) Matsum. \& Nakai), were obtained from designated fruits store in Ojo Area $\left(6.4579^{\circ} \mathrm{N}, 3.1580^{\circ} \mathrm{E}\right)$ of Lagos, Nigeria. Proper identification and authentication of the fruits were done at the Department of Botany, Lagos State University, Lagos, by Dr. O. J. Sharaibi with the reference numbers LSH/20/651, LSH/20/652, LSH/20/653, and LSH/20/654 for apple, banana, pawpaw, and watermelon, respectively. The fruits were washed under running tap water to remove sand. Pawpaw, watermelon, and apple were peeled and sliced, and their seeds were removed, while banana was only peeled. This is followed by extraction of the juice from all the fruits using household juice extractor. The juice was centrifuged, filtered, and the supernatant freeze-dried in a lyophilizer. The percentage yield of the extracts of apple, banana, pawpaw, and watermelon is $10.50 \%, 6.71 \%, 23.24 \%$, and $45.27 \%$, respectively. Extracts were dissolved in distilled water to give stock solutions of $1.0 \mathrm{mg} / \mathrm{mL}$ and different concentrations (12.5, $25,50,100$, and $200 \mu \mathrm{g} / \mathrm{mL}$ ) of the extracts were prepared using serial dilution method with distilled water. All extracts were stored at $4{ }^{\circ} \mathrm{C}$ prior to analysis.

\section{Aldose reductase inhibition assay}

The aldose reductase inhibition assay was performed according to the method of [10] with minor modifications. The reaction mixture contained $0.15 \mathrm{mM}$ NADPH, 10 $\mathrm{mM}$ DL-glyceraldehyde, $5 \mu \mathrm{L}$ of aldose reductase, and $100 \mu \mathrm{L}$ of fruit extract $(12.5-200 \mu \mathrm{g} / \mathrm{mL})$ or distilled water in a total volume of $1.0 \mathrm{~mL}$ of $100 \mathrm{mM}$ sodium phosphate buffer ( $\mathrm{pH}$ 6.2). After the reaction mixtures were incubated at $25^{\circ} \mathrm{C}$ for $5 \mathrm{~min}$ in advance, the reaction was initiated by addition of the enzyme, and then the change in absorbance was measured at $340 \mathrm{~nm}$ for 10 min using a Cary50 Bio UV-VIS spectrophotometer. The aldose reductase inhibition activity was calculated as percentage inhibition, thus

$\%$ Inhibition $=\left[\left(\Delta \mathrm{Abs}_{\text {control }}-\Delta \mathrm{Abs}_{\text {extract }}\right) / \Delta \mathrm{Abs}_{\text {control }}\right] \times 100$

The inhibition assay of the standard (quercetin) was performed using the same procedure but replacing the extract with quercetin $(12.5-200 \mu \mathrm{g} / \mathrm{mL})$. The concentration of extract or standard (quercetin) that inhibited $50 \%$ of aldose reductase activities $\left(\mathrm{IC}_{50}\right)$ were evaluated using Microsoft Excel (2010).

\section{Kinetics of inhibition of aldose reductase by C. papaya}

The kinetics of inhibition of aldose reductase by aqueous extract of pawpaw (Carica papaya) was performed according to the method described by [11]. In one set of tubes, the reaction mixture contained $0.15 \mathrm{mM} \mathrm{NADPH}$, DL-glyceraldehyde $(10-200 \mathrm{mM}), 5 \mu \mathrm{L}$ of aldose reductase, and $100 \mu \mathrm{L}$ of pawpaw extract $(50 \mu \mathrm{g} / \mathrm{mL})$ in a total volume of $1.0 \mathrm{~mL}$ of $100 \mathrm{mM}$ sodium phosphate buffer ( $\mathrm{pH}$ 6.2). In another set of tubes, $100 \mu \mathrm{L}$ distilled water replaced the pawpaw extract and this serves as control. The change in absorbance was measured at $340 \mathrm{~nm}$ and converted to reaction velocities. Lineweaver-Burk plot was plotted to determine the mode of inhibition.

\section{Sorbitol dehydrogenase inhibition assay}

Sorbitol dehydrogenase inhibition activity was determined in accordance with the method of [12]. The assay mixture contained $100 \mathrm{mM}$ tris- $\mathrm{HCl}$ buffer (pH 9.0), $0.5 \mathrm{mM}$ $\mathrm{NAD}^{+}, 50 \mu \mathrm{L}$ sorbitol dehydrogenase, $100 \mathrm{mM}$ sorbitol (substrate), and fruit extract $(12.5-200 \mu \mathrm{g} / \mathrm{mL})$. The reaction was initiated by the addition of $\mathrm{NAD}^{+}$. The rate of change in the absorbance of the mixture was measured at $340 \mathrm{~nm}$ using a Cary50 Bio UV-VIS spectrophotometer. 
The sorbitol dehydrogenase inhibition activity was calculated as percentage inhibition, thus

$\%$ Inhibition $=\left[\left(\Delta \mathrm{Abs}_{\mathrm{control}}-\Delta \mathrm{Abs}_{\text {extract }}\right) / \Delta \mathrm{Abs}_{\text {control }}\right] \times$ 100

The inhibition assay of the standard (quercetin) was performed using the same procedure but replacing the extract with quercetin $(12.5-200 \mu \mathrm{g} / \mathrm{mL})$. The concentration of extract or standard (quercetin) that inhibited $50 \%$ of aldose reductase activities $\left(\mathrm{IC}_{50}\right)$ were evaluated using Microsoft Excel (2010).

\section{Kinetics of inhibition of sorbitol dehydrogenase by $C$. papaya}

The kinetics of inhibition of sorbitol dehydrogenase by aqueous extract of pawpaw (Carica papaya) was performed according to the method described by [13]. In one set of tubes, the reaction mixture contained $100 \mathrm{mM}$ tris$\mathrm{HCl}$ buffer (pH 9.0), $0.5 \mathrm{mM} \mathrm{NAD}{ }^{+}, 50 \mu \mathrm{L}$ sorbitol dehydrogenase, sorbitol (100-500 mM), and $50 \mu \mathrm{g} / \mathrm{mL}$ pawpaw extract. In another set of tubes, distilled water replaced the pawpaw extract and this serves as control. The change in absorbance was measured at $340 \mathrm{~nm}$ and converted to reaction velocities. Lineweaver-Burk plot was plotted to determine the mode of inhibition.

\section{Phytochemical analysis}

Due to the low $\mathrm{IC}_{50}$ values of pawpaw extract for the inhibition of aldose reductase and sorbitol dehydrogenase, the qualitative and quantitative phytochemical composition of the pawpaw extract was determined using the modified spectrophotometric methods of $[14,15]$, respectively.

\section{Statistical analysis}

All analyses were performed in triplicates unless otherwise stated. Data were expressed as mean \pm SEM and statistical significance was considered at $p<0.05$. $\mathrm{IC}_{50}$ values were obtained from percentage inhibitions using Microsoft Excel software (Microsoft, 2010). Analysis of variance (ANOVA) was used to assess differences in the percentage inhibitions and $\mathrm{IC}_{50}$ values of the extracts as well as standard. Kinetics of inhibition of enzymes were determined by linear regression using GraphPad Prism statistical package (GraphPad Software, USA).

\section{Results}

Figure 1 shows the inhibitory potential of four selected fruits on the activities of aldose reductase and sorbitol dehydrogenase. At higher concentrations, there are significant differences $(p<0.05)$ between percentage inhibition of aldose reductase and sorbitol dehydrogenase by apple extract. However, their values are similar at $12.5 \mu \mathrm{g} / \mathrm{mL}$ (Fig. 1a). Banana extract displayed a higher inhibition of aldose reductase at all concentrations tested but was only significantly different at 25 and $50 \mu \mathrm{g} / \mathrm{mL}$ (Fig. 1b). At all concentrations tested, pawpaw and watermelon extract significantly inhibited the activity of sorbitol dehydrogenase than aldose reductase (Fig. 1c, d).

Table 1 shows the $\mathrm{IC}_{50}$ values for the inhibition of aldose reductase and sorbitol dehydrogenase by selected fruits. Pawpaw extract exhibited the lowest $\mathrm{IC}_{50}$ for the inhibition of both aldose reductase $(150.78 \mu \mathrm{g} / \mathrm{mL})$ and sorbitol dehydrogenase $(46.30 \mu \mathrm{g} / \mathrm{mL})$ among all the fruits. These $\mathrm{IC}_{50}$ values are comparable to the values displayed by the standard, quercetin. Banana and apple extract also exhibited similar $\mathrm{IC}_{50}$ values as pawpaw extract for the inhibition of aldose reductase and sorbitol dehydrogenase, respectively.

Due to the low $\mathrm{IC}_{50}$ values displayed by pawpaw for both enzymes, the kinetics of inhibition of aldose reductase and sorbitol dehydrogenase by pawpaw extract is presented in Fig. 2. From the double reciprocal plot, it revealed that aldose reductase was competitively inhibited by the pawpaw extract (Fig. 2a), due to similar maximum reaction velocity $\left(V_{\max }\right)(0.10$ and $0.11 \mathrm{mM} / \mathrm{min})$ and different Michaelis constant $\left(K_{m}\right)$ between the control and inhibited reaction (Table 2). It also inhibited sorbitol dehydrogenase in a mixed non-competitive manner (Fig. 2b), as a result of differences in both their $V_{\max }$ and $K_{m}$ (Table 2).

Qualitative phytochemical screening of the pawpaw extract showed the presence of flavonoids, glycosides, phenolics, tannins, and alkaloid. Quantitative analysis revealed that pawpaw extract contains $2.75 \mathrm{mg} / \mathrm{g}$ flavonoids (quercetin equivalent), $63.15 \mathrm{mg} / \mathrm{g}$ phenolics (gallic acid equivalent), and $2.13 \mathrm{mg} / \mathrm{g}$ tannins (tannic acid equivalent).

\section{Discussion}

The rising global incidence of diabetes mellitus and severity of its associated complications necessitated the need for safer and more effective strategies to combat it. As such, several processes have been targeted in the pathogenesis and progression of diabetes for possible exploit for therapeutic purposes. These include the hexosamine pathway, protein glycosylation, oxidative stress, and polyol pathway [16]. Several studies have established the inevitable link between polyol pathway and development of diabetic complications like kidney disease, cataract, and cardiovascular disorder $[2,17]$.

In this study, we evaluated the inhibitory effect of polyol pathway enzymes by four fruits, apple (Malus domestica), banana (Musa paradisiaca), pawpaw (Carica papaya), and watermelon (Citrullus lanatus), as a possible mechanism underlying hypoglycemic potential of the fruits. Of the fruits selected, pawpaw displayed the lowest $\mathrm{IC}_{50}$ for the inhibition of both aldose reductase $(150.78 \mu \mathrm{g} / \mathrm{mL})$ and sorbitol dehydrogenase $(46.30 \mu \mathrm{g} /$ $\mathrm{mL})$. This is an indication that pawpaw effectively inhibited the activities of both enzymes in the polyol pathway. The mechanism involved is that the enzyme inhibition prevents the intracellular accumulation of sorbitol and 

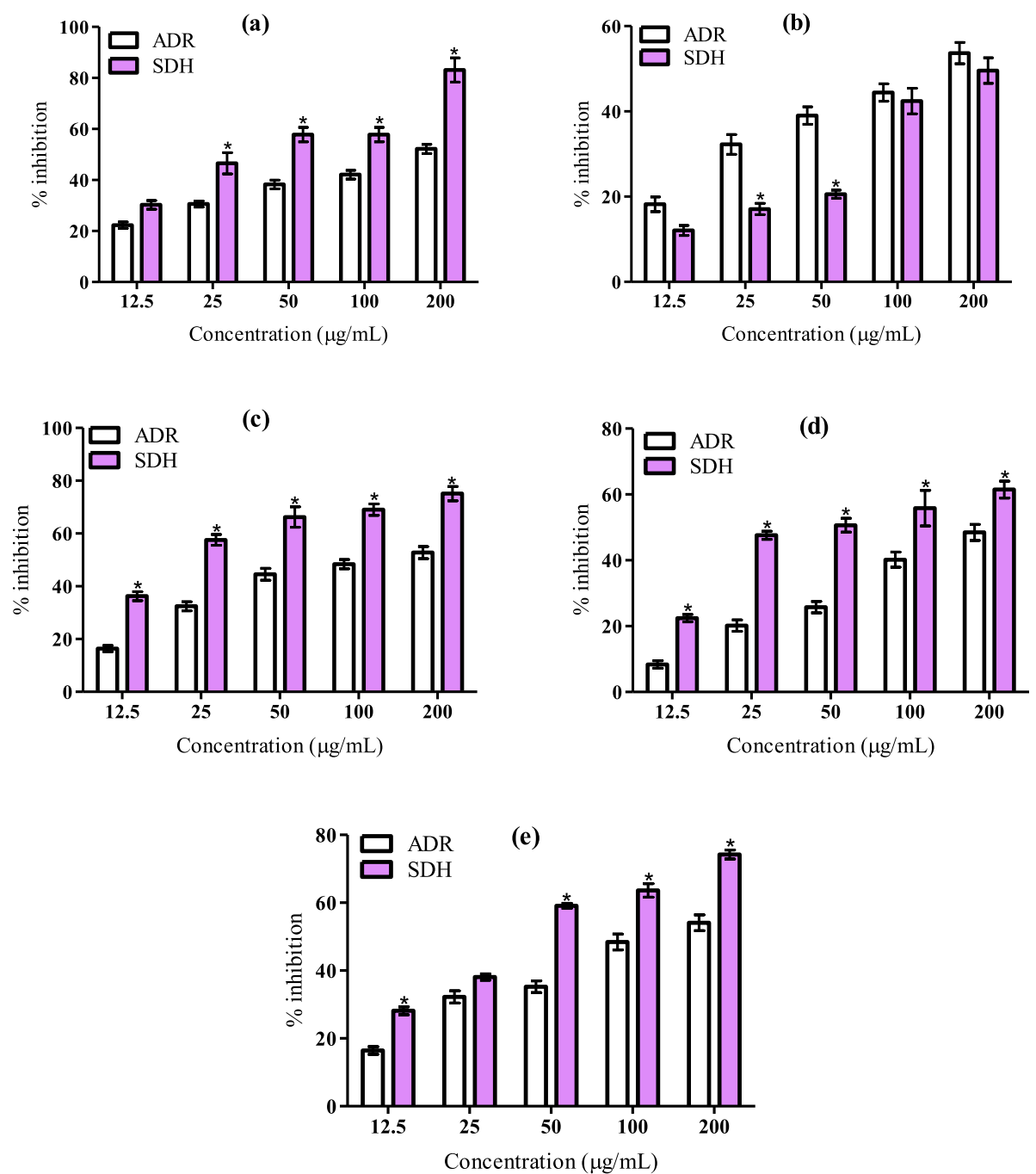

Fig. 1 Inhibitory effect of a apple (Malus domestica), b banana (Musa paradisiaca), c pawpaw (Carica papaya), d watermelon (Citrullus lanatus) extract, and e quercetin on the activities of aldose reductase and sorbitol dehydrogenase. ADR, aldose reductase; SDH, sorbitol dehydrogenase, Asterisk indicates values are significantly different at $p<0.05$

fructose [18], thereby mitigating osmotic stress and glycation, respectively. It also prevents the depletion of NADPH [1], which is normally required by the cell for regeneration of reduced glutathione, which plays the role of antioxidant. Inhibition of the enzymes by pawpaw extract, therefore, prevents cellular oxidative stress and redox imbalance, thereby ameliorating diabetic complications (Fig. 3).

The fact that $\mathrm{IC}_{50}$ values (for the inhibition of aldose reductase and sorbitol dehydrogenase) exhibited by

Table $1 \mid C_{50}$ values for the inhibition of aldose reductase and sorbitol dehydrogenase by selected tropical fruits

\begin{tabular}{lll}
\hline Fruits & \multicolumn{1}{l}{$\mathbf{C}_{\mathbf{5 0}}(\boldsymbol{\mu \mathbf { g } / \mathbf { m L } )}$} & Sorbitol dehydrogenase \\
\cline { 2 - 3 } & Aldose reductase & $56.52 \pm 4.95^{\mathrm{a}}$ \\
\hline Apple (Malus domestica) & $171.63 \pm 5.42^{\mathrm{a}}$ & $185.10 \pm 13.40^{\mathrm{b}}$ \\
Banana (Musa paradisiaca) & $159.16 \pm 5.01^{\mathrm{b}}$ & $46.30 \pm 1.59^{\mathrm{a}}$ \\
Pawpaw (Carica papaya) & $150.78 \pm 4.53^{\mathrm{b}}$ & $96.60 \pm 7.04^{\mathrm{c}}$ \\
Watermelon (Citrullus lanatus) & $189.13 \pm 14.37^{\mathrm{a}}$ & $67.50 \pm 0.83^{\mathrm{a}}$ \\
Quercetin & $153.85 \pm 5.38^{\mathrm{b}}$ &
\end{tabular}

The values are expressed as means \pm SEM of triplicate determinations. Means down vertical column not sharing a common letter are significantly different $(p<$ 0.05 ) from each other 

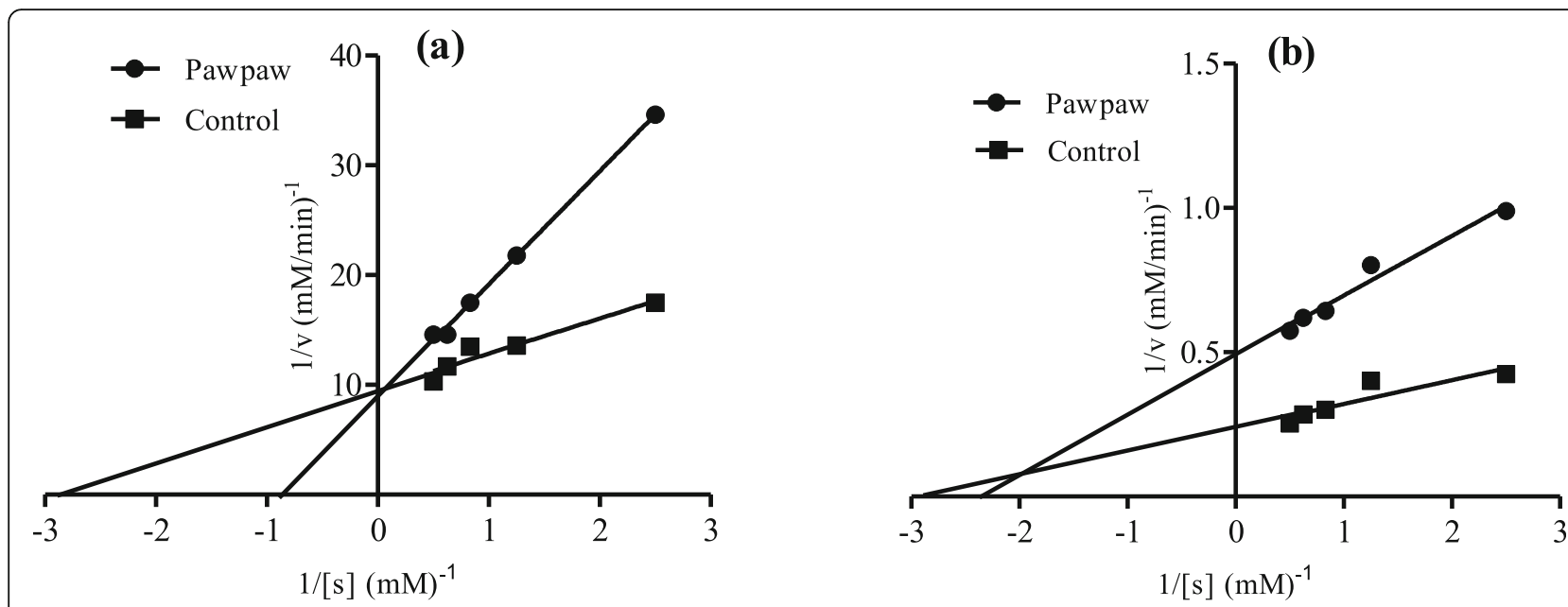

Fig. 2 Modes of inhibition of a aldose reductase and $\mathbf{b}$ sorbitol dehydrogenase by aqueous extract of pawpaw (Carica papaya) fruit. Control, absence of the inhibitor; Pawpaw, presence of the inhibitor

pawpaw is similar to the standard (quercetin) depicts the high potency of pawpaw. This is because quercetin has been demonstrated to possess strong inhibition against enzymes of the polyol pathway and is therefore used widely as positive control [19]. This is due to the possession of structural features required for binding to the active site of the enzymes. Quercetin also inhibits aldose reductase and sorbitol dehydrogenase in a variety of mechanism including competitive, non-competitive, and uncompetitive inhibition [20].

As a follow-up to the inhibitory potential, aqueous extract of pawpaw was used to determine the kinetics of inhibition of both aldose reductase and sorbitol dehydrogenase. Double reciprocal plot revealed that pawpaw extract inhibited aldose reductase and sorbitol dehydrogenase in competitive and mixed non-competitive manner, respectively. The competitive inhibition of aldose reductase by the pawpaw extract implies the inhibitory component of the extract compete with the normal substrate (glucose) for binding to the active site of the enzyme, thereby forming enzyme-inhibitor complex and preventing catalysis [21]. This competition may be due to the structural resemblance between the inhibitor and the substrate. The mixed non-

Table 2 Enzyme kinetics for the inhibition of aldose reductase and sorbitol dehydrogenase by pawpaw (Carica papaya) fruit extract

\begin{tabular}{llll}
\hline Enzyme & Sample & $\boldsymbol{K}_{\boldsymbol{m}}(\mathbf{m M})$ & $\boldsymbol{V}_{\max }(\mathbf{m M} / \mathbf{m i n})$ \\
\hline Aldose reductase & Control & 0.33 & 0.10 \\
& Pawpaw & 1.16 & 0.11 \\
Sorbitol dehydrogenase & Control & 0.35 & 0.42 \\
& Pawpaw & 0.42 & 2.04 \\
\hline
\end{tabular}

Values presented were obtained from the double reciprocal plot prepared using GraphPad Prism statistical package. $K_{m}$ Michaelis constant, $V_{\max }$ maximum velocity of reaction competitive inhibition of sorbitol dehydrogenase by the pawpaw extract suggests the inhibitory components bind to either the enzyme or enzyme-substrate complex but have different affinities for both the enzyme and enzyme-substrate complex [22]. This also prevents catalysis and the polyol does not proceed, thereby ameliorating diabetic complications.

The fact that pawpaw extract displayed the most effective inhibition of polyol pathway enzymes is a confirmation of plethora of studies that reported hypoglycemic and antidiabetic potentials of pawpaw [23-27]. The ripe fruit of pawpaw is eaten raw or can be cooked as soup with other spices. Due to its huge nutritional and medicinal effects, the ripe fruit is fermented with food-grade yeast to produce fermented pawpaw preparation and marketed across the globe [28]. The fermented pawpaw preparation has been validated to possess hypoglycemic activity in both animal model of diabetes mellitus and diabetic subjects [29]. The wound-healing activity of the aqueous extract of pawpaw [30, 31] and fermented pawpaw preparation in diabetic animals has also been reported [32].

The potent inhibitory effect of the pawpaw extract on aldose reductase and sorbitol dehydrogenase depicts that one of the antidiabetic mechanisms of the fruit is the inhibition of polyol pathway enzymes. This inhibitory activity may be due to the presence of phytochemicals such as phenolics, flavonoids, tannins, glycosides, and alkaloids [23]. Pawpaw fruit is characterized with the presence of several classes of bioactive compounds including phenolics (e.g., myricetin, quercetin, kaempferol, caffeic, and ferulic acid) and carotenoids (such as lycopene and $\beta$ carotene) $[33,34]$. The presence of these phytochemicals especially phenolics may be responsible for polyol pathway enzymes' inhibitory effect of the fruit, which may contribute to the amelioration of diabetic complications. 

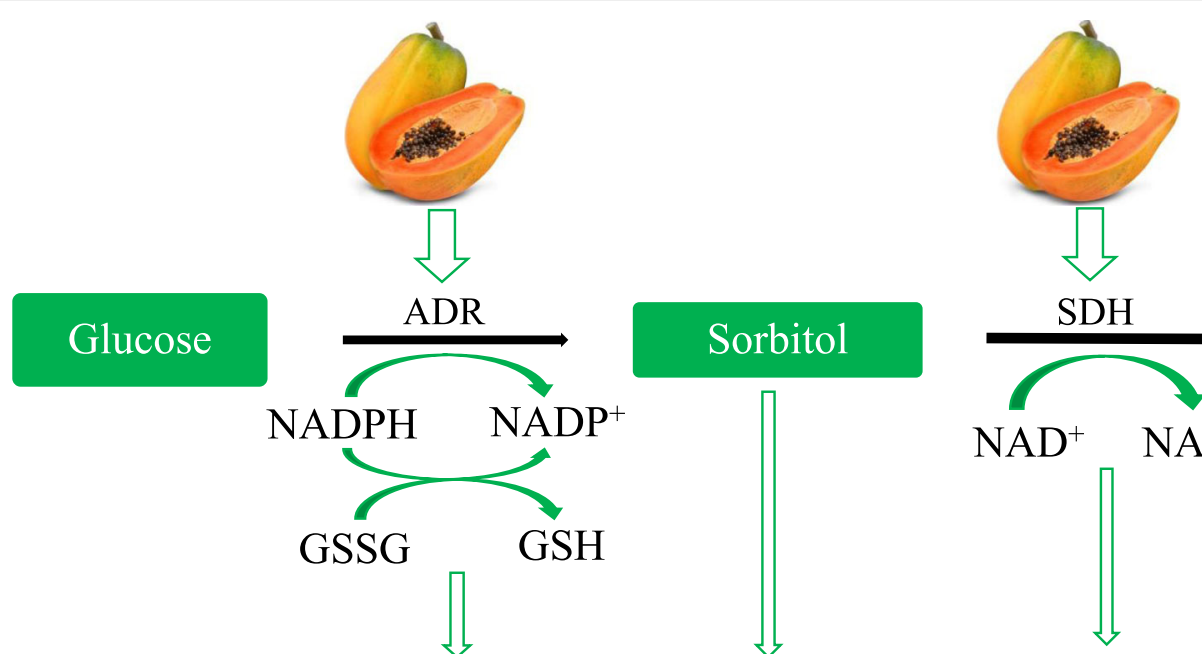

Glucose
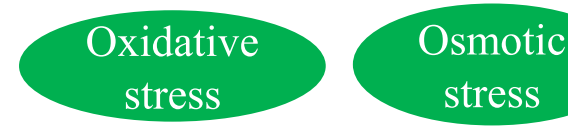

stress
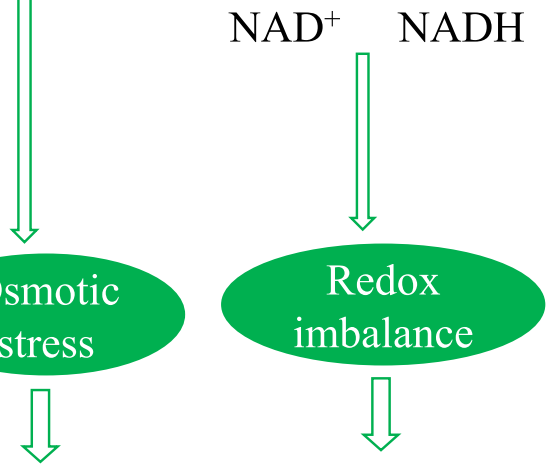

\section{Fructose}

Diabetic complications: Nephropathy, neuropathy, retinopathy

Fig. 3 Possible mechanisms involved in the inhibition of polyol pathway enzymes by pawpaw (Carica papaya) extract, and its amelioration of diabetic complications. ADR, aldose reductase; SDH, sorbitol dehydrogenase; GSH, reduced glutathione; GSSG, glutathione disulfide; NADP nicotinamide adenine dinucleotide phosphate; NADPH, reduced nicotinamide adenine dinucleotide phosphate; NAD ${ }^{+}$, nicotinamide adenine dinucleotide; $\mathrm{NADH}$, reduced nicotinamide adenine dinucleotide

\section{Conclusion}

It can therefore be concluded that fruits tested in this study displayed some inhibitory properties against polyol pathway enzymes. However, pawpaw exhibited the best inhibitory properties against the enzymes, and the mode of inhibition of aldose reductase and sorbitol dehydrogenase is competitive and mixed non-competitive inhibition, respectively. The inhibition of polyol pathway enzymes by the pawpaw extract may contribute to the amelioration of diabetic complications. This potential may be attributed to the inherent phytochemicals present in the fruit. Bioassay-guided fractionation is required to isolate the bioactive compounds responsible for the enzyme inhibition and confirmation in in vivo model of diabetic complication.

\section{Abbreviations}

ADR: Aldose reductase; AGEs: Advanced glycation end products;

GSH: Reduced glutathione; GSSG: Glutathione disulfide; NAD ${ }^{+}$: Nicotinamide adenine dinucleotide; NADH: Reduced nicotinamide adenine dinucleotide; NADPH: Reduced nicotinamide dinucleotide phosphate;

$\mathrm{NADP}^{+}$: Nicotinamide dinucleotide phosphate; SDH: Sorbitol dehydrogenase

\section{Acknowledgements}

The authors hereby acknowledge the management of Lagos State University, for providing the platform to perform this study.
Plant authentication

Proper identification and authentication of the fruits were done at the Department of Botany, Lagos State University, Lagos.

\section{Authors' contributions}

MIK: Conception of the study, design of the study, and project supervision. AAA: Conduct of experiment and generation of data. AFA: Design of the study and preparation of the manuscript draft. MAA: Design of the study, data analysis, and preparation of manuscript draft. All authors have read and approved the manuscript.

\section{Funding}

This research did not receive any specific grant from funding agencies in the public, commercial, or not-for-profit sectors.

\section{Availability of data and materials}

Data and material are available upon request.

Ethics approval and consent to participate Not applicable

\section{Consent for publication}

Not applicable

\section{Competing interests}

The authors declare that they have no competing interests.

\section{Author details}

'Department of Biochemistry, Faculty of Science, Lagos State University, Ojo, Lagos, Nigeria. ${ }^{2}$ Department of Medical Biochemistry, Faculty of Basic Medical Sciences, Lagos State University College of Medicine, Ikeja, Lagos, Nigeria. 
Received: 15 June 2020 Accepted: 21 September 2020

Published online: 22 November 2020

\section{References}

1. Lorenzi M (2007) The polyol pathway as a mechanism for diabetic retinopathy: attractive, elusive, and resilient. Journal of Diabetes Research 2007: doi. https://doi.org/10.1155/2007/61038

2. Chung SSM, Ho ECM, Lam KSL, Chung SK (2003) Contribution of polyol pathway to diabetes-induced oxidative stress. J Am Soc Nephrol 14(suppl 3):S233-\$236

3. Dunlop M (2000) Aldose reductase and the role of the polyol pathway in diabetic nephropathy. Kidney Int 58(Suppl 77):S3-S12

4. Jang S-M, Kim M-J, Choi M-S, Kwon E-Y, Lee M-K (2010) Inhibitory effects of ursolic acid on hepatic polyol pathway and glucose production in streptozotocin-induced diabetic mice. Metab Clin Exp 59(4):512-519

5. Dembinska-Kiec A, Mykkänen O, Kiec-Wilk B, Mykkänen H (2008) Antioxidant phytochemicals against type 2 diabetes. British Journal of Nutrition 99(E-S1): ES109-ES117.

6. Muraki I, Imamura F, Manson JE, Hu FB, Willett WC, van Dam RM, Sun Q (2013) Fruit consumption and risk of type 2 diabetes: results from three prospective longitudinal cohort studies. British Medical Journal 347: f5001 doi. https://doi.org/10.1136/bmj.f5001

7. Devalaraja S, Jain S, Yadav H (2011) Exotic fruits as therapeutic complements for diabetes, obesity and metabolic syndrome. Food Res Int 44(7):1856-1865

8. Hernández-Alonso P, Camacho-Barcia L, Bulló M, Salas-Salvadó J (2017) Nuts and dried fruits: an update of their beneficial effects on type 2 diabetes. Nutrients 9(7):673

9. Survay NS, Ko E-Y, Upadhyay CP, Jang M, Park S-W, Lee D-H, Jung Y-S, Yoon D-Y, Hong S-J (2010) Hypoglycemic effects of fruits and vegetables in hyperglycemic rats for prevention of type-2 diabetes. Horticultural Science \& Technology 28(5):850-856

10. Fatmawati S, Ersam T, Shimizu K (2015) The inhibitory activity of aldose reductase in vitro by constituents of Garcinia mangostana Linn. Phytomedicine 22(1):49-51

11. Dongare V, Kulkarni C, Kondawar M, Magdum C, Haldavnekar V, Arvindekar A (2012) Inhibition of aldose reductase and anti-cataract action of trans-anethole isolated from Foeniculum vulgare Mill. Fruits Food chemistry 132(1):385-390

12. Kobayashi T, Kaneco T, luchi Y, Matsuki S, Takahashi M, Nakada T, Fujii J (2002) Localization and physiological implication of aldose reductase and sorbitol dehydrogenase in reproductive tracts and spermatozoa of male rats. J Androl 23(5):674-684

13. Lindstad Rl, Teigen K, Skjeldal L (2013) Inhibition of sorbitol dehydrogenase by nucleosides and nucleotides. Biochem Biophys Res Commun 435(2):202-208

14. Akanji MA, Yakubu MT, Kazeem MI (2013) Hypolipidemic and toxicological potential of aqueous extract of Rauvolfia vomitoria Afzel root in wistar rats. J Med Sci 13(4):253-260

15. Oyedemi SO, Oyedemi BO, Arowosegbe S, Afolayan AJ (2012) Phytochemicals analysis and medicinal potentials of hydroalcoholic extract from Curtisia dentata (Burm. F) Ca Sm stem bark. Int J Mol Sci 13(5):6189-6203

16. Brownlee M (2001) Biochemistry and molecular cell biology of diabetic complications. Nature 414(6865):813-820

17. Saraswat M, Muthenna P, Suryanarayana P, Petrash JM, Reddy GB (2008) Dietary sources of aldose reductase inhibitors: prospects for alleviating diabetic complications. Asia Pac J Clin Nutr 17(4):558-565

18. Brownlee M (2005) The pathobiology of diabetic complications: a unifying mechanism. diabetes 54(6):1615-1625

19. Aslan HE, Beydemir \$ (2017) Phenolic compounds: the inhibition effect on polyol pathway enzymes. Chem Biol Interact 266:47-55

20. Stefek M, Karasu C (2011) Eye lens in aging and diabetes: effect of quercetin. Rejuvenation Res 14(5):525-534

21. Nelson DL, Cox MM (2009) Enzymes. In: Lehninger principles of biochemistry. 4th ed. WH Freeman New York.

22. Berg JM, Tymoczko JL, Stryer L (2007) Glycolysis and gluconeogenesis. W. H. Freeman and Company, New York

23. Saeed F, Arshad MU, Pasha I, Naz R, Batool R, Khan AA, Nasir MA, Shafique B (2014) Nutritional and phyto-therapeutic potential of papaya (Carica papaya Linn.): an overview. Int J Food Prop 17(7):1637-1653

24. Ali A, Devarajan S, Waly M, Essa MM, Rahman MS (2011) Nutritional and medicinal value of papaya (Carica papaya L.). Natural products and bioactive compounds in disease prevention. New York: Nova Science Publishers: 34-42.

25. Adenowo AF, Ilori MF, Balogun FO, Kazeem MI (2014) Protective effect of ethanol leaf extract of Carica papaya Linn (Caricaceae) in alloxan-induced diabetic rats. Trop J Pharm Res 13(11):1877-1882

26. Juárez-Rojop IE, Díaz-Zagoya JC, Ble-Castillo JL, Miranda-Osorio PH, CastellRodríguez AE, Tovilla-Zárate CA, Rodríguez-Hernández A, Aguilar-Mariscal H, Ramón-Frías T, Bermúdez-Ocaña DY (2012) Hypoglycemic effect of Carica papaya leaves in streptozotocin-induced diabetic rats. BMC Complementary and Alternative Medicine 12(1): 236 doi: https:/doi.org/10.1186/1472-6882-12-236.

27. Juárez-Rojop IE, Tovilla-Zárate CA, Aguilar-Domínguez DE, Roa-de la Fuente LF, Lobato-García CE, Blé-Castillo JL, López-Meraz L, Díaz-Zagoya JC, BermúdezOcaña DY (2014) Phytochemical screening and hypoglycemic activity of Carica papaya leaf in streptozotocin-induced diabetic rats. Rev Bras 24(3):341-347

28. Nafiu AB, Alli-Oluwafuyi A, Haleemat A, Olalekan IS, Rahman MT (2019) Papaya (Carica papaya L., pawpaw)(ed) nonvitamin and nonmineral nutritional supplements. Elsevier:335-359.

29. Somanah J, Putteeraj M, Aruoma Ol, Bahorun T (2018) Discovering the health promoting potential of fermented papaya preparation - its future perspectives for the dietary management of oxidative stress during diabetes. Fermentation 4(4): 83 doi: https://doi.org/10.3390/fermentation4040083.

30. Anuar NS, Zahari SS, Taib IA, Rahman MT (2008) Effect of green and ripe Carica papaya epicarp extracts on wound healing and during pregnancy. Food Chem Toxicol 46(7):2384-2389

31. Nayak BS, Pereira LP, Maharaj D (2007) Wound healing activity of Carica papaya L. in experimentally induced diabetic rats. Indian J Exp Biol 45:739-743

32. Collard E, Roy S (2010) Improved function of diabetic wound-site macrophages and accelerated wound closure in response to oral supplementation of a fermented papaya preparation. Antioxid Redox Signal 13(5):599-606

33. Ikram EHK, Stanley R, Netzel M, Fanning K (2015) Phytochemicals of papaya and its traditional health and culinary uses-a review. J Food Compos Anal 41:201-211

34. Rivera-Pastrana DM, Yahia EM, González-Aguilar GA (2010) Phenolic and carotenoid profiles of papaya fruit (Carica papaya L.) and their contents under low temperature storage. J Sci Food Agric 90(14):2358-2365

\section{Publisher's Note}

Springer Nature remains neutral with regard to jurisdictional claims in published maps and institutional affiliations.

\section{Submit your manuscript to a SpringerOpen ${ }^{\circ}$ journal and benefit from:}

- Convenient online submission

- Rigorous peer review

- Open access: articles freely available online

- High visibility within the field

Retaining the copyright to your article

Submit your next manuscript at $>$ springeropen.com 